\title{
Cutaneous Trunci
}

National Cancer Institute

\section{Source}

National Cancer Institute. Cutaneous Trunci. NCI Thesaurus. Code C52901.

The thin skeletal muscle within the subcutaneous tissue. 